\title{
医学情報マネージメントの観点からの情報リテラシィ教育
}

\author{
董 田 和 夫* \\ 東京慈恵会医科大学医学情報センター
}

Urata K. (Medical Information Center, Jikei University School of Medicine. 3-25-8, NishiShinbashi, Minato-ku, Tokyo 105, Japan) : Education of Information Literacy in the Aspect of Medical Information Management. Igaku Toshokan 1997 ; 44(3) : 303-307.

The Medical Information Center of Jikei University, where the author is employed, has education programs on information literacy for undergraduate and graduate students. Medical information management is considered a pivotal concept in the activities of learning, education, research, practice, and administration, and this concept has been introduced as the basis of our education programs on information literacy. Here the author describe his discussions on the design of programs, including lectures and practical exercises. Several problems regarding human and physical educational resources which cannot be overlooked in carrying out information literacy education are also mentioned. Other education programs conducted by our center are also described.

\section{I 。過去の概略}

東京慈恵会医科大学医学情報センター（以下， 当センター）が正規のカリキュラムにおいて行っ た最初の教育活動は, 昭和 63 （1988）年度に生 理学のグループ研修の一環として担当した文献検 索の実習であった。医学科 3 年生全員を対象とし た講義が 90 分, その後 5 班に分割され，毎週 1 班ごとセンターの図書館に来て, さらに 6 組の小 人数に分け，それぞれに図書館員がついて指導員 となり，文献情報の検索法の実習を行うあのであ る (150 分)。この方法は平成 5 （1993）年度ま で続けられ, 指導員となった図書館員の意識向上 にも良い機会であったが, 問題点もいくつかあり, 筆者により報告している ${ }^{1)}$ 。

その後, 平成 6 （1994）年度より, グループ研

“Kazuo URATA：=105 東京都港区西新橋 3-25-8.

(1997 年 6 月 26 日 受理)
修は基礎医学演習という対象を 4 年生とし, 基礎 医学講座や研究室がそれぞれ提示する主題コース （それを提示した講座や研究室）を学生が選択し て学習する科目へと変更になり，全学生が同様な テーマで実習を受けることができないことに問題 が残るものの, ともかく当センターを選択した学 生がその提供するコースを学習することになった。

毎週水曜日の午後半日, 10 回にわたり当セン ターへ来て実習するというあので，この時に初め て文献情報の検索法だけではなく，医学生として 必要な情報マネージメントのための基礎知識と技 術を学んであらうことを目的とした，コース内容 の編成を行うことになった。

また，同年度から，本学の情報処理研究室が担 当していた大学院 1 年生に対する共通カリキュラ ム告) の医学情報コース（全日，2 週間）を担当す ることになり, 学部学生以上に情報マネージメン トの観点を意識したコースの編成を行った ${ }^{2)}$ 。平 成 8 （1996）年度からは共通カリキュラムに参加 
する研究室が多くなり，1週間に短縮されたコー スを現在は運営している。

\section{III 情報マネージメント教育の必要}

医学の学習, 教育, 研究, 診療活動, さらには 組織として情報マネージメントが必要であること はマセソン・クーパー・レポート光をいまさら引 用するまでもないであろうが，その第 5 章で既に, 情報マネージメント教育が大切なのであって, 図 書館教育ではなく，コンピュータと情報マネージ メントの技法を最大限に活用することである，と 強調している。

一口に情報マネージメントといっても，具体的 にそれは何を学生に理解させることなのか, 大変 難しい問題である。ただ，図書館の利用について, これあ知っておいてあらいたい，あれあ知ってお いてあらわないと，といった図書館の諸サービス の利用法に関して微に入り細をうがった教育はマ セソンに否定されている。また，現在もそうだが, 近い将来に図書館や情報サービスを利用する，あ るいは情報システムの開発に関与する学生に対す る教育であって, 図書館・情報学を専攻する学生 に対する教育ではないことを強く意識しなければ ならない。

一方, 医療情報学（medical informatics）の 教科書, 教育の必要性に関する論文は米国を中心 に数多く出版されているが，日本の医学教育との 異なりがあり, また, それらで提唱されている教 育内容は, 当センターで教育できる範囲を, 知識・ 技術においても，施設・設備においても超越して おり，満足できるレベルまで採用することは到底 不可能である。

\section{III. 慈恵での現在の教育内容}

他の機関の医学図書館や医学情報サービス部門 と異なって，当センターには専任教員が 4 名いる が, 既に紹介してあるように ${ }^{4)}$, 教育と研究に専 念していれば良いというのではなく，七ンターの 業務を遂行する一員であり, 学生に対する教育で あってもセンターの教育サービスとしてとらえて いる。また, 教員のうち 2 名は図書館・情報学の 出身, 1 名は電気工学を専攻したシステム専門家, もう1名は医師であり，米国で医療情報学を学ん だ者であるが，今年 6 月からの採用で，これまで の検討には加わってはいない。また, 当センター は図書館部門のほかに, 標本館, 写真室, 史料室, 医療情報研究室があり, 教員, 図書館員, 研究技 術員, 事務員の複数の職種の混成所帯であり, 教 育は主に教員によってなされるが，実習に当たっ てはそれぞれの専門的立場から補助をしてくれて いる。

種々の考察を経て, 基礎医学演習にも大学院の 共通カリキュラムにも, 次の要素を中心としたコー スを編成することにした。

1）医学・医療領域の多様な情報資源之情報処 理

2）医学文献情報

3) 医療統計処理

4) 医学とコンピュータ・ネットワーク

5) プレゼンテーション技法（主に, パソコン によるスライド作成）

つまり,コンピュータをはじめとする今日の多 様なメディアの時代にあって, 情報の入手・利用・ 処理，いわゆる情報リテラシィの基本を習得して あらうことを目的としている。当然のことながら, 学部と大学院では教育レベルが異なるし, 学生の

注）本学の大学院生は 10 名前後と少なく, 全員が臨床経験が 2 年以上あり, 既に講座, 研究室に所属している。共通力リキュ ラムは, 彼らが研究活動を進めていくうえでの基礎知識・技術を習得させるために設けられている。平成 9 (1997) 年度は, 4 月 3 日より 6 月 13 日まで 8 つの教育・研究部門が担当。大学院生は 18 名。 
裹田 医学情報マネージメントの観点からの情報リテラシィ教育

積極性も大きく異なる。

表 1 に今年度（1997）に担当した大学院 1 年生 の共通カリキュラムのコース内容を示す。実習機 器の台数の関係で, 2 班に分け, 同様内容を繰り 返している（当センターと同じく, 一度に学生を 収容できない研究室ああり, 分割しながらのカリ キュラム進行に混乱はない)。なお, 表中の医学 統計, 統計ソフトウェア・パッケージ SAS の使 い方, DNA データベース, そして医用画像につ いては学内の他の講座や研究室の教員に担当を願っ た。

表 1. 平成 9 年度大学院共通カリキュラム 「医学情報コース」プログラム

$\begin{array}{lll}\text { 第1 日目 } & \text { 午前 } & \text { インターネット入門 } \\ & \text { 午後 } & \text { 医用画像 } \\ \text { 第2 日目 } & \text { 午前 } & \text { インターネット実習 } \\ & \text { 午後 } & \text { DNA データベース } \\ \text { 第3 日目 } & \text { 午前 } & \text { 医学統計 } \\ & \text { 午後 } & \text { SAS 実習 } \\ \text { 第 4 日目 } & \text { 午前 } & \text { 論文発表の論理と倫理 } \\ & & \text { 情報検索とデータベース } \\ & \text { 午後 } & \text { プレゼンテーション技法 (1) } \\ \text { 第 5 日目 } & \text { 午前 } & \text { プレゼンテーション技法 (2) } \\ & \text { 午後 } & \text { 文献情報検索実習 } \\ \text { 第6 日目 } & \text { 午前 } & \text { 医学論文の読み方 } \\ & & \text { 医学論文の書き方とUniform } \\ & & \text { Requirements }\end{array}$

医学情報センター以外の教員の都合を優先したので，コース 内容は必ずしも秩序立った編成となってはいない。これと同様 内容がもう1班に対しても行われる。講義は大学院講義室で主 として行い, インターネット, DNA データベース, SAS, プ レゼンテーションの実習は医学情報センタ一医療情報研究室, 文献情報検索実習は図書館の端末装置のコーナーで行っている。 午前の部は 9 時または 9 時 30 分に開始し， 12 時頃まで，午後 の部は 13 時より 17 時までが担当時間である。
以上のほかに，正規のカリキュラムとして医学 部看護学科 3 年生（国領キャンパス）に対する情 報科学を担当している。これは 90 分, 15 コマの あので, 看護と情報マネージメントを中心テーマ に, コンピュータの社会的, 文化的側面も含め講 義している。実習については, 同じキャンパス内 の医学科国領校 ( $1 \cdot 2$ 年生) の情報処理実習室 で自主的に行うよう指導している。

\section{IV. 新カリキュラムへの移行期}

平成 5（1993）年度から看護学科之同様に医学 科 2 年生（国領キャンパス）に対しても情報科学 を担当してきた。しかし, 誰むが承知のように, コンピュータ処理はいかに基礎的知識といえども 実習が必要である。その考えから筆者らは，約 100 名の学生の実習が可能な時間割を大学として 計画するか, 筆者らが講義の時のみ西新橋キャン パスから出向くのではなく（電車で約 90 分の距 離), 国領キャンパスに常時いる教員が教育を担 当し，同時に学生の自主的学習にいつでも相談に のれる体制をとるべきとの提案を行ったが，ちょ うどカリキュラムの大幅な改訂に取り組んでいた カリキュラム委員会にその提案が受け入れられ, 平成8（1996）年度から国領キャンパスの教員に より，実習を主とした教育が 1 年生を対象に開始 されている(新カリキュラムでは対象を 2 年生か ら 1 年生へ変更)。

一方, カリキュラム委員会は高学年に対し医学 情報に関するコースの必要を提唱し, 現在, 当セ ンターや他の講座, 研究室との共同で担当する内 容の検討を行っているところである。

\section{V. 多様な公開コース}

以上の学部と大学院への教育担当のほかに, 2 つの看護専門学校の情報科学が加わる。1つの学 
校は 1 部生， 2 部生をかかえているので， 3 つの 情報科学コース（90 分, 15 コマ）を担当してい ることになる。コース内容を，主に文献情報の検 索法とパソコンでのワープロと表計算におき， ンターネットの利用を含む最近の情報処理技術の 進展を実演を含めて講義したり, 本学の病院での コンピュータ導入の現状を見学したりしている。 パソコン実習の部分は本学の電算部門の協力を得 ている。

医科大学には多様な職種が存在する。学生時代 にグループ研修で文献情報の検索法の実習を受け たが，今やすっかり記憶にない新入医局員，教授 や教室員の文献入手を依頼される教室秘書や研究 補助員，看護婦，医療技術員などである。それに あ增して，これまで稼働してきた情報システムを 改訂したり，変更したりした場合には，それらを 周知させる機会を設けることが重要となる。平成 8 年度には次のような講習会を開催した。

1) 文献情報検索講習会（MEDLINE，医学中 央雑誌を中心として, Current Contents, Journal Citation Reports む対象)。特に職種を 限っていないが，若手を主とした医師・医学研究 者の参加が多い。平成 8 年度は CD-ROM シス テムを SilverPlatter 社から Ovid 社のものに変 更したこともあり，52 回と頻回に開催し，144 名 の参加を得ている。1 回, 約 50 分。

2）医療情報活用コース（教室秘書, 研究補助 員を対象)。基礎コース 2 回，アドバンスコース 2 回, 8 名参加。引用文献リストの見方, 文献の探 し方, CD-ROM データベースによる文献デー夕 の確認法, 文献リストの作成法など。1回，約 90 分。

これらのほかに, 本学の 2 つの雑誌編集委員会 の共催で, 本学の医学英語の非常勤講師や他の大 学から講師を招いたりして毎年開催する医学英語 論文の書き方講習会も当センターが担当し，また， パソコンによるスライド作成法の講習会も当セン
ターの写真室員が講師をつとめ, 不定期な開催で はあるが好評である。

\section{VI. 学生による評価}

今年度の大学院共通カリキュラムのコース終了 後に受講した感想レポートを提出させた。2,000 字以内としたので，十分に表現できなかったよう であるが，全員が真剣に考察し，意見を書いてく れた。概㸚当センターによる医学情報コースはよ く構成されており, 研究活動の出発にあって有益 な内容であったと賞賛してくれている。

「文献情報の検索法で検索機能の多様性や論理 的な検索展開の必要か理解できた」「「インターネッ 卜を介して利用できる医学情報資源の多様・多種 さを知り, また研究の進めに有効な手段であるこ とを確認した」,「医学統計をむっと時間をかけて, SAS のみでなく，一般的な統計ソフトゥェアの 解説も希望する」,「論文の読み方や論文の書き方 はこのコース以外にきちんと教育される機会がな いので有益であった」などの文章を, 提出された レポートから拾うことができた。すっとも，採点 される立場なので，本音よりはよく述べてくれた ようではあるが。

\section{VII. いくつかの課題と問題点}

先にも述べたが，医学・医療の領域において， どこにどのような情報資源があり，どうすれば自 分に関心のある情報が見つかり，その情報が本当 に有益なものかどうか判断できるような方法を身 につけ，それを研究や診療に活かし，データの解 析や発表の時に使用する図表, スライドなどが作 成でき，論文を執筆するよい手順を自分の習慣と させることができる。また, 当然のことながら, いかなる今日のメディアにも対応できる。このよ うな教育像を描いてコース内容を組み立ててきた 
し，また，この基本姿勢は本報告の論題に表現さ せていただいた。

医学情報センターの運営やサービス活動を本務 としながらの教育活動である。いくら, 教育サー ビスとして当センターの役割の 1 つに組み入れて あ，忙中に講義や実習の準備を行うのはかなり厳 しいものがある。そこには，また，教育者として 教育や実習を行う今日的方法の訓練も必要とされ よう。

また, 教育を担当しているわれわれ誰あが現在 のコースの編成で十分とは考えていない。医療情 報学の範囲をさらに追求する必要があろう。幸い 米国で医療情報学を専攻した教員が当センターの 一員になった。彼から教えてあらうことが多いと 期待している。

既に医学統計は臨床の医師に依頼しているが, 筆者は,このようなコースには臨床医からのアプ ローチがあっと必要であると考えている。医師が 診療上のある問題に遭遇したときの解決の方法, 判断の方法も含めたいし，筆者が担当した臨床医 の医学論文の読み方, つまり臨床の研究結果をど う評価し，それをどう患者に応用するかに関して も含めたい。1993 年から雑誌 JAMAに現在も 掲載されているUsers' guides to the medical literature の解説こそは, 医学判断法にも関心が あり，臨床経験も十分にある医師に教壇に立って あらいたいと切に思う。そのためには, 学内の人 材を探し求めねばならないし，この領域で著名な 研究者に本学まで来て講義をしていただきたいが, それに対する資金的裏付けあ必要となる。

また，ほかで既に実在し，実現可能性の十分に ある医学・医療システムの講義を行っても, 実習 に使用したり，実際に利用する施設・設備が本学 は残念ながら十分に整備されているとはいえず, ここにも問題が存在する。

\section{参考文献}

1 ）裏田和夫. コンピュータの活用 : 学術情報入手の手 段としての利用. 日本医学教育学会教育技法委員会 編. 臨床教育マニュアルーこれからの教え方, 学び 方一. 東京 : 篠原出版, $1994: 277-81$.

2 ) 裏田和夫. 事例 : 東京慈恵会医科大学. 日本私立大 学連盟学術情報サービス分科会編.ネットワーク時 代の学術情報支援. 東京: 開成社, 1995: 303-11.

3) Matheson NW, Cooper JAD (津田良成ほ加訳). 医科大学における学術情報マネージメント，東京：

慶応義塾大学医学情報センター, 1987.

4) 裏田和夫. 先人に学びながら進める計画づくり（加 盟館紹介: 東京慈恵会医科大学医学情報センター). 医学図書館 1996 ; 43(4)：419-21. 